Louisiana State University

LSU Digital Commons

Faculty Publications

Department of Chemistry

3-1-2008

\title{
Reactions of acenaphthenequinone and aceanthrenequinone with arenes in superacid
}

\author{
Douglas A. Klumpp \\ Northern Illinois University \\ Yiliang Zhang \\ Northern Illinois University \\ Dat Do \\ Cal Poly Pomona \\ Rendy Kartika \\ Cal Poly Pomona
}

Follow this and additional works at: https://digitalcommons.Isu.edu/chemistry_pubs

\section{Recommended Citation}

Klumpp, D., Zhang, Y., Do, D., \& Kartika, R. (2008). Reactions of acenaphthenequinone and aceanthrenequinone with arenes in superacid. Applied Catalysis A: General, 336 (1-2), 128-132.

https://doi.org/10.1016/j.apcata.2007.08.036

This Article is brought to you for free and open access by the Department of Chemistry at LSU Digital Commons. It has been accepted for inclusion in Faculty Publications by an authorized administrator of LSU Digital Commons.

For more information, please contact ir@lsu.edu. 


\title{
Reactions of Acenaphthenequinone and Aceanthrenequinone with Arenes in Superacid
}

\author{
Douglas A. Klumpp ${ }^{\ddagger}$, , Yiliang Zhang ${ }^{\ddagger}$, Dat Do ${ }^{\dagger}$, and Rendy Kartika ${ }^{\dagger}$ \\ ‡Department of Chemistry and Biochemistry, Northern Illinois University, DeKalb, Illinois, 60115 \\ tDepartment of Chemistry, California State Polytechnic University, Pomona, California, 90178
}

\begin{abstract}
The hydroxyalkylation reactions of aceanthrenequinone (6) and acenapthenequinone (7) with a series of arenes have been studied. In reactions with the Brønsted superacid $\mathrm{CF}_{3} \mathrm{SO}_{3} \mathrm{H}$ (triflic acid), the condensation products are formed in good yields (58-99\%, 10 examples) with high regioselectivity. Computational studies were also done to examine the structures and energies of mono- and diprotonated species from $\mathbf{6}$ and $\mathbf{7}$. The results from the condensation reactions are consistent with the formation of superelectrophilic species involving protosolvation of carboxonium ion intermediates.
\end{abstract}

\section{Introduction}

The acid-catalyzed condensation of aromatic compounds and aldehydes or ketones is known as the hydroxyalkylation reaction. ${ }^{1}$ Examples of this conversion date back to 1872 , when it was reported that chloral condenses with benzene in sulfuric acid. ${ }^{2}$ The hydroxyalkylation reaction is the basis for a number of industrially important synthetic conversions, including the preparation of bis-phenol monomers for polycarbonate resins, the preparation of dyes such as malachite green, and in the preparation of some pharmaceuticals. Recently, there have been several reports involving superacid-catalyzed condensations of 1,2-dicarbonyl compounds with benzene and other arenes. Shudo and Ohwada found that 2,3-butanedione (1) gives the condensation product (3) in high yield, and the diprotonated species (2) was proposed as an intermediate (eq 1). ${ }^{3}$ Similar reactions were used to prepare the anticonvulsant drug, phenytoin (4), from parabanic acid (eq 2) and the high molecular weight condensation polymer (5) from isatin (eq 3). ${ }^{4,5}$ In each of these examples, diprotonated or superelectrophilic intermediates are thought to be involved in the condensation reactions. The hydroxyalkylation reaction often requires the aromatic compound to be an activated system (i.e. nucleophilic) like phenol or an aryl ether. With non-activated or deactivated arenes (benzene, chlorobenzene, nitrobenzene), the condensation reaction can only occur with a highly electrophilic reactant. Superelectrophilic carboxonium ions and those substituted by strong electron withdrawing groups $\left(-\mathrm{CF}_{3}\right.$ or $\left.-\mathrm{CCl}_{3}\right)$ have been shown to react with even deactivated arenes in the hydroxyalkylation reaction. ${ }^{6}$

(C) 2007 Elsevier B.V. All rights reserved.

dklumpp@niu.edu.

Publisher's Disclaimer: This is a PDF file of an unedited manuscript that has been accepted for publication. As a service to our customers we are providing this early version of the manuscript. The manuscript will undergo copyediting, typesetting, and review of the resulting proof before it is published in its final citable form. Please note that during the production process errors may be discovered which could affect the content, and all legal disclaimers that apply to the journal pertain. 



A survey of the literature shows that there are very few general examples of the hydroxyalkylation reaction involving quinones. An exception is the acid-catalyzed chemistry of aceanthrenequinone (6) and acenaphthenequinone (7). It has been shown in several studies that these quinone systems condense with pyrroles in good yields from $\mathrm{CF}_{3} \mathrm{CO}_{2} \mathrm{H}$ or $\mathrm{BF}_{3}-\mathrm{Et}_{2} \mathrm{O} .7$, Pyrroles are reactive, electron-rich aromatic compounds and their condensation chemistry is well known in porphyrin synthesis. Recently two reports have described the syntheses of high molecular weight polymers based on this superacidcatalyzed condensation chemistry of $7 .{ }^{8}$ In the following manuscript, we provide a full report of the chemistry aceanthrenequinone and acenaphthenequinone in superacidcatalyzed hydroxyalkylation reactions with arenes. We demonstrate that quinones 6 and 7 condense with benzene and related arenes in good to excellent yields, and a mechanism is proposed which invokes the formation of diprotonated, superelectrophilic quinones. The protonated structures are further characterized by theoretical calculations.

\section{Experimental}

\subsection{General}

Aceanthrenequinone (6), acenaphthenequinone (7), solid acid catalysts, trifluoroacetic acid, and $98 \% \mathrm{H}_{2} \mathrm{SO}_{4}$ were purchased from commercial suppliers and used as received.

Trifluoromethanesulfonic acid (triflic acid) was purchased from a commercial supplier and it was distilled from an Ar atmosphere prior to use.

\subsection{Procedure for the Preparation Condensation Products}

Aceanthrenequinone $(0.2 \mathrm{~g}, 0.86 \mathrm{mmol})$ is dissolved in $1 \mathrm{~mL}$ of arene and $3 \mathrm{~mL} \mathrm{CF}_{3} \mathrm{SO}_{3} \mathrm{H}$ is added. After stirring for at least 4 hours at $25^{\circ} \mathrm{C}$, the mixture is poured over ice. The resulting solution is then extracted twice with $\mathrm{CHCl}_{3}$ and the organic phase is washed 
thoroughly with water and then brine. The solution is then dried with $\mathrm{MgSO}_{4}$ and concentrated in vacuo to give the product. The crude product is then purified by column chromatography (if necessary) or recrystallization. All new compounds have been completely characterized by ${ }^{1} \mathrm{H}$ and ${ }^{13} \mathrm{C}$ NMR spectroscopy, elemental analysis or highresolution mass spectroscopy, and in the case of product 2,2-Diphenyl- $2 \mathrm{H}$-aceanthrylen-1one $(\mathbf{8})$, single crystal x-ray crystallography. ${ }^{9}$ With acenaphthenequinone, the products were sufficiently volatile for analysis by gas chromatography.

\section{Results}

When aceanthrenequinone (6) is reacted with $\mathrm{C}_{6} \mathrm{H}_{6}$ in the Brønsted superacid $\mathrm{CF}_{3} \mathrm{SO}_{3} \mathrm{H}$, the condensation product (8) is formed in excellent yield (eq 4). Like the condensation of $\mathbf{6}$ with pyrrole ${ }^{7 \mathrm{~b}}$ nucleophilic attack by benzene occurs exclusively at 2-carbonyl group. A series of arenes were reacted with aceanthrenequinone $(6)$ and $\mathrm{CF}_{3} \mathrm{SO}_{3} \mathrm{H}$ and the expected condensation products $(\mathbf{8 - 1 2})$ are formed regioselectively in good yields (Table 1). NMR analysis indicates that a single regioisomer is produced in the reactions of toluene and halobenzenes. In previous studies, other 1,2-dicarbonyl compounds have likewise shown good regioselectivity in hydroxyalkylation reactions. ${ }^{4,5 \mathrm{~b}}$ The condensation reaction with benzene can be effected by as little as 3.0 equivalents of $\mathrm{CF}_{3} \mathrm{SO}_{3} \mathrm{H}$. With $98 \% \mathrm{H}_{2} \mathrm{SO}_{4}$, product $\mathbf{8}$ is formed in just $26 \%$ yield from aceanthrenequinone (6) and benzene, while trifluoroacetic acid does not give any condensation product.

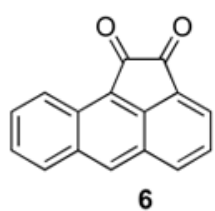

6



$94 \%$

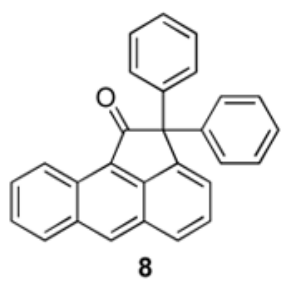

8

Acenaphthenequinone (7) also condenses with arenes in strongly acidic or superacidic media. When compound 7 is reacted with $\mathrm{CF}_{3} \mathrm{SO}_{3} \mathrm{H}$ and a series of arenes, the condensation products (13-17) are also formed regioselectively in good yields (Table 1). Unlike aceanthrenequinone (6) however, the condensation reactions of acenaphthenequinone (7) generate some side-products, and the composition of the product mixtures varies considerably with the reaction conditions. For example with benzene, three types of products are formed in reactions with $\mathbf{7}$ in acidic media (Table 2). The optimal conditions for conversion to the hydroxyalkylation product $(\mathbf{1 3})$ were found to be the reaction with a large excess (ca. 40 equivalents) of $\mathrm{CF}_{3} \mathrm{SO}_{3} \mathrm{H}$ at $0^{\circ} \mathrm{C}$. At higher temperatures, an increasing amount of product (18) is formed from a dehydrative cyclization reaction. An unusual acenaphthylene product (19) is also formed at $80^{\circ} \mathrm{C}$, presumably from the reduction of cationic intermediates. Although $\mathrm{H}_{2} \mathrm{SO}_{4}$ gives some condensation product, none is obtained from $\mathrm{CF}_{3} \mathrm{CO}_{2} \mathrm{H}$ or various solid acids (Table 2). If the hydroxyalkylation product (13) is isolated and reacted with $\mathrm{CF}_{3} \mathrm{SO}_{3} \mathrm{H}\left(\mathrm{no}_{6} \mathrm{H}_{6}\right)$, the dehydrative cyclization product $(\mathbf{1 8})$ is formed in good yield (eq 5). Similar conversions were described involving dehydrative cyclizations of aryl-pinacols and 2,2,2-triphenylacetophenone (20). ${ }^{10}$ In the superacid promoted dehydrative cyclization of $\mathbf{2 0}$, experimental evidence suggested the involvement of an $O, O$-diprotonated superelectrophile. An analogous diprotonated species (21) is proposed in the dehydrative cyclization (eq 5), with an initial step involving a phenyl migration to the carboxonium position. ${ }^{10}$ 


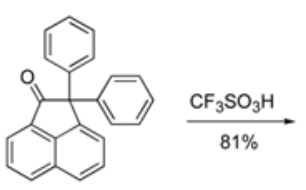

13

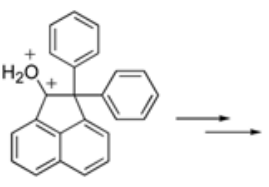

21



18

In order to further explore these superacid-catalyzed condensation reactions, DFT calculations were done to determine the structures and energies of likely protonated intermediates from aceanthrenequinone $(6)$ and acenaphthenequinone (7). ${ }^{11} \mathrm{~A}$ recent manuscript reported the structures and energies for mono and diprotonated acenaphthenequinone (7) with geometry calculations done at the B3LYP/6-31G* level of theory and single point energy calculations done at the aug-ccpvtz(-f) level. ${ }^{9}$ Even with solvation taken into account however, these calculations suggested that diprotonated, superelectrophilic intermediates were unlikely based on the energies of these intermediates. Our calculations at the B3LYP/6-311G**//B3LYP/6-311G** level ${ }^{12}$ are in partial agreement with the earlier study: the most stable diprotonated structures (22c and 23c) arise from sequential protonation at each of the carbonyl oxygens (Figure 2). Stationary points were also found at several $C, O$-diprotonated structures and at structures in which protonation occurs twice on the same carbonyl group, but in each of these cases the dicationic structures are significantly less stable than the global minima. Interestingly, the most stable monoprotonated species from aceanthrenequinone $(\mathbf{6})$ is found at structure 22a in which the 1-carbonyl group is protonated. In the acid-catalyzed condensation reactions however, nucleophilic attack occurs at the 2-carbonyl group to give product 8 (eq 4). In order for the acid-catalyzed reaction to give product $\mathbf{8}$, the reaction must involve the 2carbonyl-protonated species (22b) or a superelectrophilic intermediate. Based on the calculations, however, ion $22 \mathbf{b}$ is $5 \mathrm{kcal} / \mathrm{mol}$ less stable than 22a. This suggests that a diprotonated species (i.e. 22c,d) is the reacting electrophile in the condensation reaction.

\section{Discussion}

The widely accepted mechanism for the hydroxyalkylation reaction involves formation of a carboxonium ion by protonation of a carbonyl group, followed by nucleophilic attack by the arene. For the condensation reactions of aceanthrenequinone (6) and acenaphthenequinone (7), there are three possibilities: the condensations occur through only monoprotonated intermediates and transition states, the condensations occur through monoprotonated intermediates with protosolvation of the transition states (and partial dicationic character), or the condensations occur by the involvement of discrete, fully formed, dicationic superelectrophiles. In this study, there are several lines of evidence to suggest that superelectrophiles with partial or full dicationic character are involved in the condensation reactions of aceanthrenequinone (6) and acenaphthenequinone (7). Benzene and chlorobenzene are arenes with relatively low strength as nucleophiles. With these arenes, electrophilic reactions require an activated carboxonium ion electrophile. This is consistent with the formation of diprotonated intermediates, such as $\mathbf{2 2 c}, \mathbf{d}$ and $\mathbf{2 3 c}, \mathbf{d}$. The condensation reactions are also shown to be sensitive to acid strength and this is often a hallmark of superelectrophilic activation. It is particularly striking that $\mathrm{CF}_{3} \mathrm{CO}_{2} \mathrm{H}$ will give hydroxyalkylation products with aceanthrenequinone (6) and pyrrole (a strong nucleophile), ${ }^{7 \mathrm{~b}}$ but the same reaction conditions give no condensation product with the less nucleophilic benzene. Furthermore, the formation of the dehydrative cyclization product (18) from acenapthenequinone (7) very likely involves the gitionic superelectrophile 21 (eq 5). This suggests that the superacidic reaction conditions are capable of forming 
carboxonium ion-based superelectrophiles. The previously reported direct observation of diprotonated acEnapthenequinone $(\mathbf{2 3 c}, \mathbf{d})$ in superacid further supports the possibility that it is a viable reactive intermediate in these conversions. ${ }^{13}$ Finally, the computational results suggest that the regiochemistry of nucleophilic attack on aceanthrenequinone (6) is best explained by invoking a diprotonated species. Although these lines of evidence suggest that diprotonated species are involved in the hydroxyalkylation reactions of compounds $\mathbf{6}$ and $\mathbf{7}$, it is not possible to determine if these are fully formed dicationic, superelectrophilic intermediates $(\mathbf{2 3 a}, \mathbf{b})$, or if they are species with only partial proton transfer. ${ }^{14}$

\section{Conclusions}

In summary, we have found that aceanthrenequinone (6) and acenapthenequinone (7) condense with moderately deactivated arenes in generally good yields in the presence of the Brønsted superacid, $\mathrm{CF}_{3} \mathrm{SO}_{3} \mathrm{H}$. It is proposed that the condensations reactions occur through superelectrophilic species involving protosolvation of carboxonium ion intermediates. While the extent of protosolvation is not known, the results suggest considerable dicationic character.

\section{Acknowledgments}

The financial support of the NIH-NIGMS (GM071368-01 and SO6GM53933-0251) is greatly appreciated. We also thank Patrick Kindelin for his assistance. This manuscript is dedicated to Professor Jean Sommer on the occasion of his $70^{\text {th }}$ birthday.

\section{References}

1. (a) Hofmann, JE.; Schriesheim, A. Friedel-Crafts and Related Reaction. Olah, GA., editor. Vol. 2. Wiley; New York, NY: 1964. p. 597-640.(b) March, J. Advanced Organic Chemistry. 4. Wiley; New York, NY: 1992. p. 548-549.

2. Baeyer A. Ber. 1872; 5:1094.

3. Yamazaki T, Saito S, Ohwada T, Shudo K. Tetrahedron Lett. 1995; 36:5749.

4. Klumpp DA, Yeung KY, Prakash GKS, Olah GA. Syn Lett. 1998:918.

5. (a) Colquhoun HM, Zolotukhin MG, Khalilov LM, Dzhemilev UM. Macromolecules. 2001; 34:1122.See also: (b) Klumpp DA, Yeung KY, Prakash GKS, Olah GA. J Org Chem. 1998; 63:4481.

6. (a) Ohwada T, Yamagata N, Shudo K. J Am Chem Soc. 1991; 113:1364.(b) Klumpp DA, Lau S. J Org Chem. 1999; 64:7309.(b) Zolotukhin M, Fomine S, Salecdo R, Khalilov L. Chem Commum. 2004:1030.(c) Kray WD, Rosser RW. J Org Chem. 1977; 42:7309.(d) Koltunov KY, Prakash GKS, Rasul G, Olah GA. Eur J Org Chem. 2006:4861.(e) Koltunov KY. Tetrahedron Lett. 2007; 48:5631.

7. (a) Harmjanz M, Gill HS, Scott MJ. J Org Chem. 2001; 66:5374. [PubMed: 11485458] (b) Harmjanz M, Bozidarevic I, Scott MJ. Org Lett. 2001; 3:2281. [PubMed: 11463296]

8. (a) Zolotukhin MG, Fomina L, Salicedo R, Sansores LE, Colquhoun HM, Khalilov LM. Macromolecules. 2004; 37:5140.(b) Zolotukhin MG, Fomine S, Lazo LM, Salcedo R, Sansores LE, Cedillo GG, Colquhoun HM, Fernandez-G JM, Khalilov LM. Macromolecules. 2005; 38:6005.

9. (a) 2,2-Diphenyl-2H-aceanthrylen-1-one (8). Yellow solid MP $210-214^{\circ} \mathrm{C}\left(\mathrm{C}_{6} \mathrm{H}_{6}\right) ; 1 \mathrm{H} \mathrm{NMR}(300$ $\mathrm{MHz}, \mathrm{CDCl} 3) \delta$, ppm: 7.20-7.36 (m, $10 \mathrm{H}), 7.45$ (d, J=6.9 Hz, 1H), 7.59-7.65 (m, 2H), 7.72-7.79 $(\mathrm{m}, 1 \mathrm{H}), 7.96(\mathrm{~d}, J=8.4 \mathrm{~Hz}, 1 \mathrm{H}), 8.17(\mathrm{~d}, J=8.4 \mathrm{~Hz}, 1 \mathrm{H}), 8.74(\mathrm{~s}, 1 \mathrm{H}), 9.22(\mathrm{~d}, J=8.7 \mathrm{~Hz}, 1 \mathrm{H}) ;{ }^{13} \mathrm{C}$ NMR (75 MHz, CDCl3) $\delta$, ppm: 67.7, 122.4, 124.5, 124.8, 125.2, 126.6, 127.0, 127.9, 128.3, 128.6, 128.7, 128.9, 129.3, 133.0, 133.8, 142.7, 143.3, 143.5, 203.8; EI MS: 370 (M+), 339, 265, 168; HRMS $\mathrm{C}_{28} \mathrm{H}_{18} \mathrm{O} \mathrm{m} / z$ calcd 370.135765 , found 370.135781. Crystal data: $\mathrm{C}_{28} \mathrm{H}_{18} \mathrm{O}$, MW 370.42, yellow crystals, triclinic, space group $P-1, \boldsymbol{a}=8.6398(18) \AA, \boldsymbol{b}=9.744$ (2) $\AA, \boldsymbol{c}=11.667$ (2) $\AA, \alpha=$ $93.702(4)^{\circ}, \beta=96.937(4)^{\circ}, \gamma=94.812(4)^{\circ}, U 968.9(3) \AA^{3}, Z=2, D_{c}=1.270 \mathrm{~g} / \mathrm{cm}^{3}, F(000) 388$, $\mu(\mathrm{MoK} \alpha) 0.075 \mathrm{~mm}^{-1}$, graphite monochromated Mo K $\alpha \lambda=0.71073 \AA$, $\mathrm{T}=293(2) \mathrm{K}$. Final discrepance factors: $R 1=0.0504$ and $w R 2=0.1323$ for 10125 reflections with $\mathrm{F}_{\mathrm{O}}>4 \sigma_{\mathrm{F}}$. 
10. Klumpp DA, Baek DN, Prakash GKS, Olah GA. J Org Chem. 1997; 62:6666.

11. Frisch, MJ.; Trucks, GW.; Schlegel, HB.; Scuseria, GE.; Robb, MA.; Cheeseman, JR.; Montgomery, JA., Jr; Vreven, T.; Kudin, KN.; Burant, JC.; Millam, JM.; Iyengar, SS.; Tomasi, J.; Barone, V.; Mennucci, B.; Cossi, M.; Scalmani, G.; Rega, N.; Petersson, GA.; Nakatsuji, H.;

Hada, M.; Ehara, M.; Toyota, K.; Fukuda, R.; Hasegawa, J.; Ishida, M.; Nakajima, T.; Honda, Y.; Kitao, O.; Nakai, H.; Klene, M.; Li, X.; Knox, JE.; Hratchian, HP.; Cross, JB.; Bakken, V.; Adamo, C.; Jaramillo, J.; Gomperts, R.; Stratmann, RE.; Yazyev, O.; Austin, AJ.; Cammi, R.; Pomelli, C.; Ochterski, JW.; Ayala, PY.; Morokuma, K.; Voth, GA.; Salvador, P.; Dannenberg, JJ.; Zakrzewski, VG.; Dapprich, S.; Daniels, AD.; Strain, MC.; Farkas, O.; Malick, DK.; Rabuck, AD.; Raghavachari, K.; Foresman, JB.; Ortiz, JV.; Cui, Q.; Baboul, AG.; Clifford, S.; Cioslowski, J.; Stefanov, BB.; Liu, G.; Liashenko, A.; Piskorz, P.; Komaromi, I.; Martin, RL.; Fox, DJ.; Keith, T.; Al-Laham, MA.; Peng, CY.; Nanayakkara, A.; Challacombe, M.; Gill, PMW.; Johnson, B.; Chen, W.; Wong, MW.; Gonzalez, C.; Pople, JA. Calculations done using Gaussian 03, Revision C.02. Vol. 2004. Gaussian, Inc; Wallingford CT: 2004.

12. (a) Becke AD. Phys Rev A. 1988; 38:3098. [PubMed: 9900728] (b) Becke AD. J Chem Phys. 1993; 98:5648.(c) Lee C, Yang W, Parr RG. Phys Rev B. 1988; 37:785.(d) Raghavachari K, Binkley JS, Seegar R, Pople JA. J Chem Phys. 1980; 72:650.

13. Bruck D, Minsky A, Dagan A, Rabinovitz M. Tetrahedron Lett. 1981; 22:3545.

14. Superelectrophilic activation involving incomplete proton transfer has been proposed in several studies, see: (a) Olah GA, Klumpp DA. Accts Chem Res. 2004; 37:211.(b) Saito S, Sato Y, Ohwada T, Shudo K. J Am Chem Soc. 1994; 116:2312.(c) Sato Y, Yato M, Ohwada T, Saito S, Shudo K. J Am Chem Soc. 1995; 117:3037.(d) Zhang Y, DeSchepper DJ, Gilbert TM, Sai KKS, Klumpp DA. Chem Comm. 2007 in press. (e) Klumpp DA, Zhang Y, O'Connor MJ, Esteves PM, de Almeida LS. Organic Letters. 2007; 9:3085. [PubMed: 17630754] 


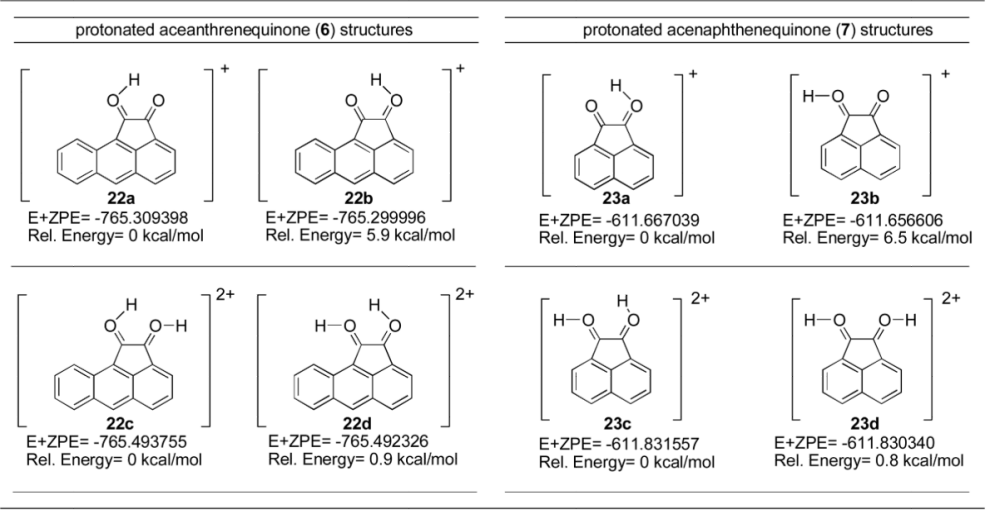

Figure 1.

Structures and energies for mono- and diprotonated structures from aceanthrenequinone (6) and acenaphthenequinone (7). ${ }^{\mathrm{a}}$

${ }^{\mathrm{a} C}$ Calculations done at the B3LYP/6-311G**//B3LYP/6-311G** level 
Table 1

Products and yields from the reactions of aceanthrenequinone (6) or acenathenequinone (7) with arenes and $\mathrm{CF}_{3} \mathrm{SO}_{3} \mathrm{H} .{ }^{a}$

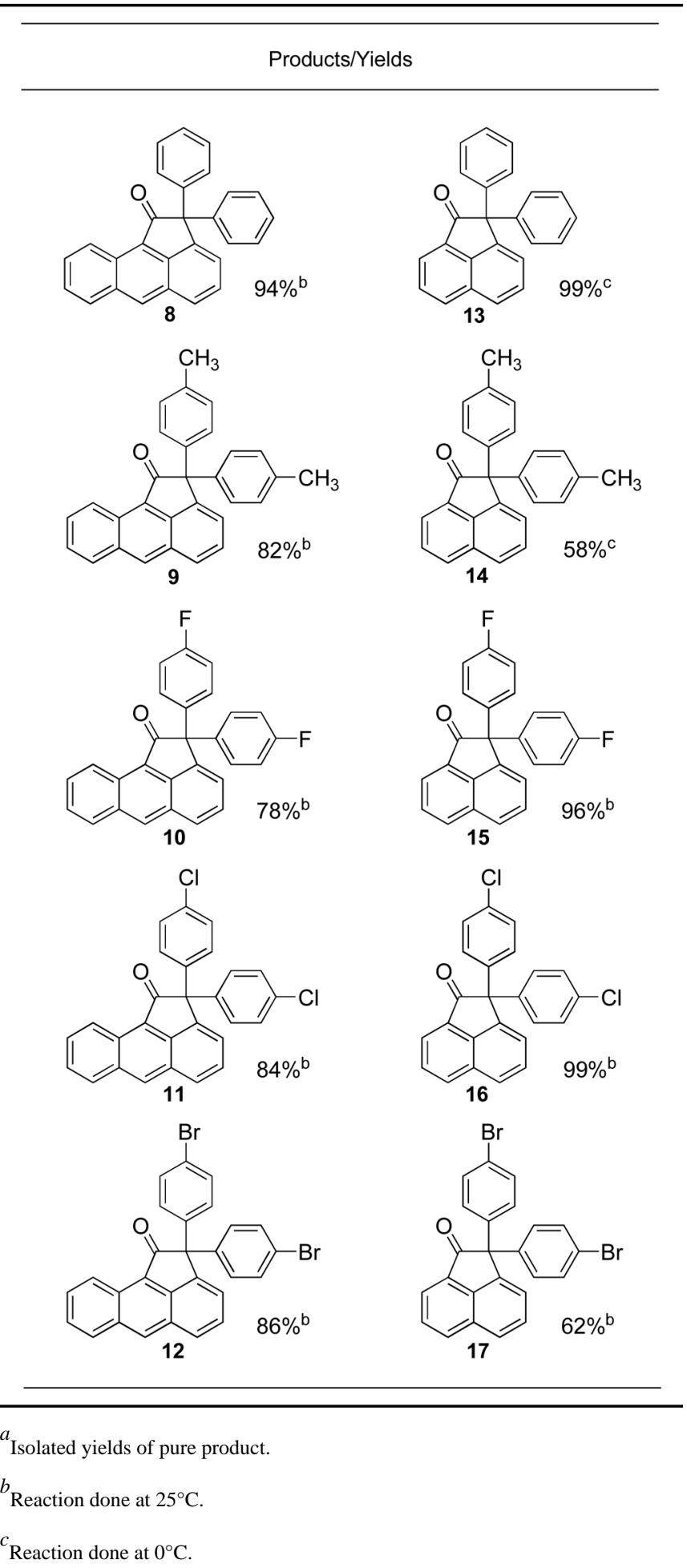

Appl Catal A Gen. Author manuscript; available in PMC 2011 September 20. 


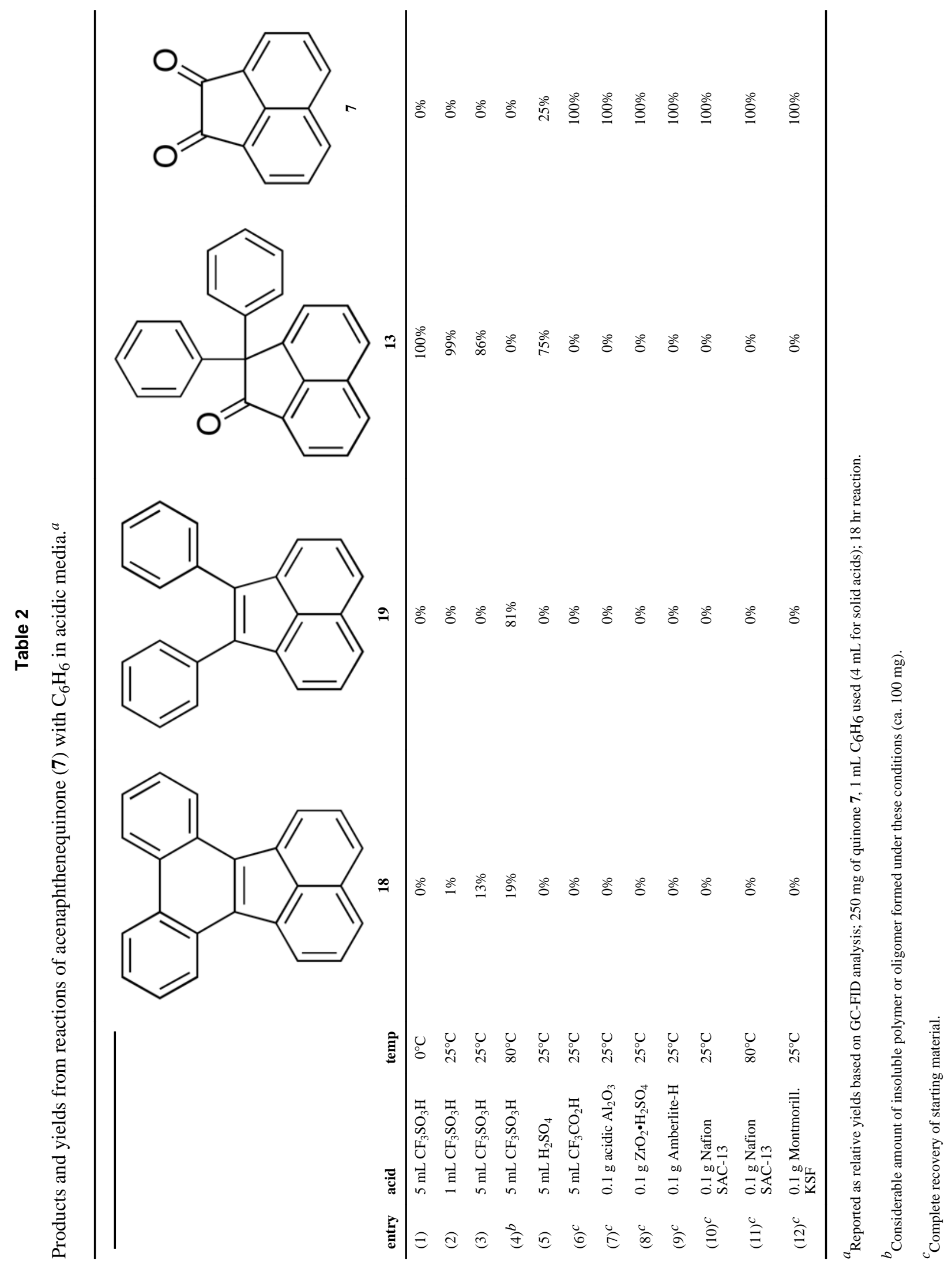

Appl Catal A Gen. Author manuscript; available in PMC 2011 September 20. 